\title{
Decentralisation of active labour market policy: The case of Swedish local employment service committees ${ }^{\S}$
}

by

\author{
Martin Lundin ${ }^{*} \&$ Per Skedinger**
}

September 22, 2000

\begin{abstract}
Decentralisation of decision-making in active labour market policy makes it possible to use local information to the fullest, but may also impinge on the fulfilment of national objectives, as suggested by principal-agent theory. The purpose of this study is to examine the effects of a Swedish pilot programme in 1996, which strengthened the role of the local authorities in labour market policy in parts of the country. Survey evidence suggests a non-negligible divergence between the objectives of the municipality representatives and the central government's goals. Regarding programme effects, our econometric findings do not indicate any increase in geographical lock-in of the unemployed, but decentralisation seems to spur local initiatives in the form of labour market programmes organised by the municipalities. In addition, targeting on outsiders is to some extent more common in municipal projects than in others.
\end{abstract}

Keywords: Active labour market policy; Decentralisation; Intergovernmental relations. JEL classification: J6; H7.

\footnotetext{
$\S$ We gratefully acknowledge comments from Magnus Wikström, Susanne Ackum Agell and seminar participants at IFAU, IUI and the Swedish Association of Local Authorities. Responsibility for any remaining errors is ours.

* Office of Labour Market Policy Evaluation (IFAU), PO Box 513, SE-751 20 Uppsala, Sweden. E-mail: martin.lundin@ifau.uu.se.

${ }^{* * *}$ Research Institute of Industrial Economics (IUI), PO Box 5501, SE-114 85 Stockholm, Sweden.E-mail: pers@iui.se.
} 


\section{Introduction}

Decentralisation of decision-making to the local level may increase the efficiency of active labour market programmes (ALMPs), since the knowledge that local authorities have about local conditions is used to its full potential. A weakness with decentralisation, however, is that it may impinge on the fulfilment on national objectives. Local authorities often face financial incentives that seem to increase this risk. For example, municipal budgets may be favourably affected by shifting persons from social assistance, which in Sweden is funded by the local authorities, to participation in labour market programmes, financed by the central government. In addition, some programmes, such as relief work, may crowd out regular municipal jobs and thus subsidise labour. The programmes may also serve as a means of increasing or maintaining local population and the municipal tax base, by reducing migration among the unemployed.

The purpose of this paper is to examine the effects of a Swedish pilot programme in 1996 that strengthened the role of the local government in labour market policy in certain municipalities. The local employment service committees (arbetsförmedlingsnämnd) in 25 municipalities were reformed so that the representatives of municipal authorities should constitute the majority of the committees' members. These committees - henceforth ESCs - are cooperative, advisory bodies at the local level and part of the National Labour Market Administration, with the purpose of adapting labour market policy to local conditions. ${ }^{1}$ Since the pilot programme affected the role of the municipalities only in certain areas of the country, it offers an opportunity to compare outcomes in the decentralised programme municipalities versus other, less decentralised, non-programme municipalities.

Empirical evidence concerning decentralisation of ALMPs should be of importance, since very little is known about the effects in general of local in-

\footnotetext{
${ }^{1}$ The ESCs should not be confused with the public employment service offices (arbetsförmedling), which also operate at the local level. The public employment service offices provide employment services and make decisions about placements in ALMPs.
} 
volvement in these policies. ${ }^{2}$ Some OECD countries have shifted the emphasis of labour market expenditures from passive measures - such as the payment of unemployment benefits - to more of active measures in the 1990s (Calmfors \& Skedinger, 1995; OECD, 1995). In addition, perceived inefficiencies in employment services have triggered a general trend towards decentralisation of ALMPs (European Commission, 1996). So far, there is only scant evidence concerning whether the efforts towards decentralisation have actually contributed to improving the effectiveness of ALMPs or not.

Traditional labour market policy in Sweden has not only emphasised active measures, but has also allowed a great deal of freedom for the National Labour Market Administration in the choice of measures for reducing unemployment. ALMPs are designed and carried out by the regional and local tiers of the Administration according to the principles of the "management by objectives" policy (mastyrning), which minimises detailed regulation (Niklasson \& Tomsmark, 1994). A new feature in recent years is that the municipalities have become increasingly involved in ALMPs, although the responsibility for these policies still lies with the government. It is estimated that in 1999 around 80,000 persons were engaged in programmes organised by the municipalities and, at least partly, financed by the government, which is roughly 40 per cent of participants in all ALMPs. In addition, some programmes are both organised and fully financed by the municipalities. Around 8,000 persons were engaged in such programmes in 1998 (Svenska Kommunförbundet, 1999). An important factor behind the involvement of the municipalities in ALMPs is that the local authorities have assumed responsibility for young people who have either quit school or not been able to find work after it. This obligation has resulted in the set-up of large programmes targeted towards youths.

Principal-agent theory, which concerns the relationship between a principal (the central government in this case) and an agent (the municipality), is applicable to the issues studied in this paper. The problem for the principal is how to make the agent act according to the objectives of the principal. The theory pre-

\footnotetext{
${ }^{2}$ Some evidence is available regarding decentralisation in other policy areas. For example, De Groot (1988) examines decentralisation of decision-making to Dutch hospitals, while King \& Ma (2000) provide evidence on the effects of fiscal decentralisation in OECD countries. For surveys regarding the effects of active labour market policies, without consideration of decentralisation issues, see Calmfors (1994) and Fay (1996). Informal discussions of the Swedish experiences of decentralisation of decision-making in labour market policy can be found in Lundin (1999), Nyberg \& Skedinger (1998) and SAF (1999).
} 
dicts that, in the presence of asymmetric information, decision-making is decentralised to the agent if (i) the divergence of objectives of the principal and agent is small enough; and (ii) local initiatives are important for the success of outcomes (Aghion \& Tirole, 1997; De Groot, 1988).

Our empirical study makes use of an events database (HÄNDEL), which contains micro-data on all registered persons in open unemployment and all participants in ALMPs in Sweden. We will also present results from a questionnaire that was distributed to a sample of ESC members. It will be examined (i) to what extent the government's and the committee members' objectives diverge; (ii) whether decentralisation is associated with geographical lock-in of the unemployed; (iii) whether decentralisation leads to an increase in local initiatives as measured by the share of participants in projects organised by the municipality; and whether (iv) municipalities are more inclined to target measures towards outsiders on the labour market than other project organisers.

The paper is organised as follows: Section 2 briefly discusses the theory of decentralisation of decision-making and how to apply it in the context of analysing ESCs. In Section 3, the committees and the pilot programme are described and evidence concerning divergence of objectives is presented. Section 4 sets out the methodology for evaluating the pilot programme effects, describes the data and reports on the econometric results. Section 5 concludes the paper.

\section{Theory of decentralisation}

The purpose of this section is to provide a theoretical background to decentralisation and to discuss its applicability to the study of local employment service committees. The discussion is quite rudimentary and a formal analysis, on which the presentation draws, is available in, e.g., Aghion \& Tirole (1997) and De Groot (1988).

An increasing literature is concerned with the principal-agent relationship, where a principal contracts an agent to undertake actions. Many different areas are characterised by this type of relationship: Stockholders vs. managers, employers vs. employees, central vs. local government, etc. An important feature in the design of the optimal contract, from the perspective of the principal, is the degree of decentralisation of decision-making to the agent. 
The literature identifies the main benefit from decentralisation as the potential to use superior information of the agent. ${ }^{3}$ Under decentralisation, the principal avoids the risk of utility loss due to incomplete information about the parameters of the problem to be solved and will thus not be forced to optimise on less precise values. It is also argued that the incentives of the decentral actor may change, with endogeneity of local initiatives, so as to increase the likelihood of successful implementation. The agent's propensity to acquire information and take own initiatives increases, to the extent that the principal credibly commits himself not to intervene. ${ }^{4}$ In addition, there may be a "commitment effect" to self-made decisions.

The main cost with decentralisation is that the principal loses control of the agent's actions. The probability that the agent undertakes actions diminishing the principal's utility increases to the extent that the interests of the two parties diverge. $^{5}$

The key aspect in the principal-agent problem is the presence of asymmetric information. Unless the agent is better informed than the principal, there is no need for decentralisation of decision-making. Decentralisation is more likely to occur when (i) there is asymmetric information; (ii) the divergence of objectives of the principal and agent is small enough; and (iii) local initiatives are important for the success of outcomes. The implications of the theory for our study of ESCs will be discussed below.

The principal is the central government and the agents are the local employment service committees, the chairman and majority of which consists of members representing the municipality. It is not difficult to accept the realism of assuming asymmetric information in the present context. The ESCs obviously are better informed about local labour market conditions, which indeed is the rationale for the setting up the committees. The municipality is a large local employer and other committee members, representing regional and local tiers

\footnotetext{
${ }^{3}$ A poorly informed principal may of course try to gather more information, but it is in many cases prohibitively costly to do so.

${ }^{4}$ According to Aghion \& Tirole (1997), overload on part of the principal is a mechanism that makes non-intervention credible.

${ }^{5}$ Investments in (costly) training, restricting the set of possible actions as well as properly designed incentives, e.g., profit-sharing in private firms, could be means of reducing the divergence itself or its effects. Incentive schemes are, however, less straightforward to apply in government bureaucracies, due to the multi-faceted objectives that typically characterise the public sector.
} 
of the National Labour Market Administration, the business community and trade unions, also are likely to possess relevant local knowledge.

The representatives of the National Labour Market Administration have a supervisory role in the committees. The set of possible actions may be restricted and information about the activities is collected and reported to the principal. It is important to note that this structure also introduces the possibility of collusion, where the supervisor acts as an advocate for the agent (Tirole, 1986).

Regarding divergence of objectives, it should be noted that the municipalities have other priorities besides providing efficient labour market policies. Municipal budgets may be favourably affected by shifting persons from social assistance, which is funded by the local authorities, to participation in labour market programmes, financed by the central government. In addition, some programmes, such as relief work, may crowd out regular jobs and thus subsidise labour in the services that typically local authorities provide, e.g., infrastructure, health, children's day-care and old age care. The programmes may also serve as a means of increasing or maintaining local population and the municipal tax base, by reducing migration among the unemployed. The potential divergence of objectives will be assessed by comparing the national objectives, as laid out in various policy documents, with questionnaire information on the views of the committee members.

We will also consider a potential consequence of diverging objectives, namely the extent to which unemployed persons are locked-in geographically. It is assumed that the jobless react to various measures undertaken by the local authorities following decentralisation. If the jobless do not anticipate the actions of the local authorities, the sequencing of effects is such that changes in the behaviour of the municipalities precede changes in lock-in. In the opposite case, e.g., if the municipalities announce changes in advance, it is possible that the jobless adapt behaviour prior to actual changes in municipal labour market policy.

A suitable measure of local initiatives is the share of ALMPs that are organised by the municipality. It is reasonable to assume that the local authorities have more control of the projects, concerning design as well as the profile of the participants, if the programme is organised by the municipality than if organised by other actors. On the one hand, this control makes it easier to use lo- 
cal information and to target measures towards groups with special needs. ${ }^{6}$ On the other hand, the possibility is introduced to pursue other goals, e.g., improving municipal budgets in ways described above. Our hypotheses are that decentralisation leads to more projects being organised by the municipality and to more focus on outsiders in the labour market.

\section{Local employment service commit- tees}

The ESCs are co-operative bodies at the local level in Sweden and part of the National Labour Market Administration. Figure 1 illustrates the position of the ESC in the organisation. In 1999, there were 283 ESCs, i.e., one in almost every municipality, with 8-16 seats in each committee. In these bodies various local representatives act together with the purpose of adapting the labour market policy to local conditions.

It is stipulated that certain interests should be represented in the committees. Members should include local representatives from the Public Employment Service offices (PES), the County Labour Boards (länsarbetsnämnd), trade unions and the business community and since 1997 the municipalities in all regions nominate the chairman and a majority of the committees' members. Apart from that, the rules governing the committees' activities are not very precise and the central government has delegated to the County Labour Boards to specify the tasks of the ESCs in more detail.

\footnotetext{
${ }^{6}$ Calmfors \& Lang (1995) argue that targeting of ALMPs towards "outsiders" increases employment, via increasing wage competition with "insiders".

7 This section is based on Government Regulation (1988:1139), Government bill (1995/96:222), Report from the Committee of Finance (1995/96:FiU15) and Lundin (1999).
} 


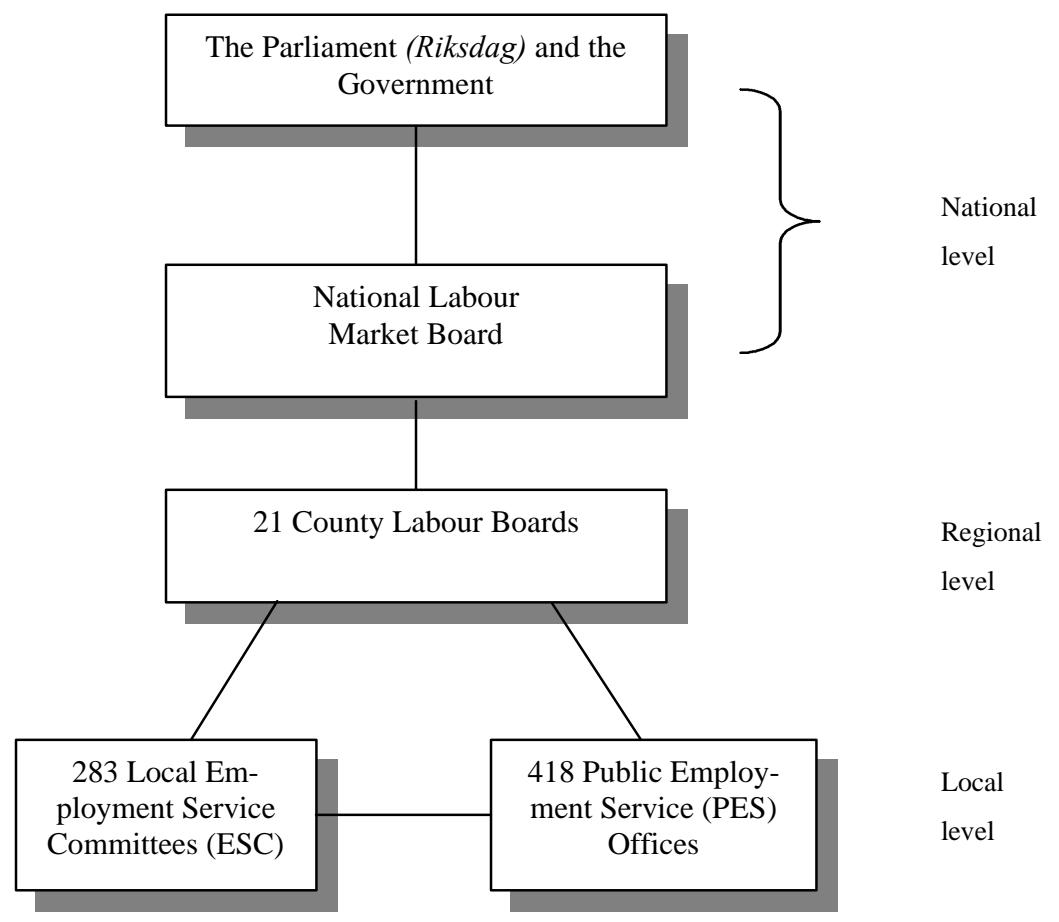

Figure 1. The Swedish National Labour Market Administration in 1999.

In a document called beslutsordning (decision-making regulations) the County Labour Boards specify the role of the ESCs. According to the documents, the ESCs should have a general collaborative function in all counties. The committees should initiate different projects, suggest changes in labour market policies when necessary and co-ordinate the activities of various actors (for example, the municipalities and the PES offices) that are carrying out and financing labour market projects. There are also some more concrete tasks defined. All County Labour Boards have delegated to the ESCs the task of appointing the budget for the PES offices and in all counties but one the committees also decide on the working plans for the offices. The task of drawing up budgets and working plans is however the responsibility of the PES offices. Through this process the ESCs lay down the broad outlines for the work at the local level. The direct influence on the budget and the working plan is probably limited, but the co-ordination of various projects and other initiatives is likely to indirectly affect the budget and the working plan. 
Other activities of the ESC vary across regions. In certain counties the committees should decide on the organisation of the PES offices, decide on the use of untraditional funding ${ }^{8}$ and prepare and comment on Objective 3 projects. The latter are partly funded by the European Union and are intended to increase employment among outsiders, i.e., young people, the handicapped, long-term unemployed and immigrants. For Objective 3 measures, the administrative hierarchy of Figure 1 applies, but there is also a parallel organisation (Ams, 1996). At the national level, there is the Monitoring Committee, the members of which represent the European Commission, the Swedish government, trade unions and employer organisations. There are also regional and local committees assisting the County Labour Boards with organising the programme. In some counties it is the ESC that serves as the local committee for Objective 3 measures.

\subsection{The 1996 pilot programme}

In 1996 the government initiated a pilot programme, in which 25 municipalities took part. ${ }^{9}$ The idea behind the programme was to gain more information about the consequences of decentralisation of active labour market policy. This study is concerned with the first part of the programme, where the role of the municipalities in the ESCs was strengthened in certain areas. Specifically, the committees should contain a majority of members from the municipal authorities and the chairman should also come from the municipality. The programme was set out to start July 1. During the course of the programme it was decided that all ESCs in the country should have a municipal majority and chairman from October 1. It turned out, however, that there were delays in fulfilling the intentions of the government in both programme and non-programme municipalities. It seems as if lags around 1-3 months have been common regarding the

\footnotetext{
${ }^{8}$ Such funding of projects allows resources to be used without some of the restrictions that apply to regular funding.

${ }^{9}$ See Government Bill (1995/96:148). The municipalities in the pilot programme were Ale, Borlänge, Falkenberg, Falun, Gullspång, Huddinge, Höganäs, Lindesberg, Malmö, Norrköping, Nybro, Nyköping, Skellefteå, Skövde, Sundbyberg, Södertälje, Trelleborg, Tyresö, Vara, Varberg, Vetlanda. Värmdö, Åre, Älmhult and Älvdalen. Two districts in the municipality of Stockholm (Rinkeby and Skarpnäck) also took part in the programme, but they have been excluded from the analysis due to lack of data.
} 
introduction of municipal majorities in the committees, although we lack full information on this issue. ${ }^{10}$

In 1997, the 25 municipalities continued in the programme, which from then on involved less restrictions regarding the use of the funds, but also requirements of partial financing on part of the municipalities (Behrenz et al., 1999). The government allowed 19 of the municipalities to continue in the programme during 1998.

Since the first part of the pilot programme (July 1 - September 30) affected the composition of the committees in only certain areas of the country, it offers an opportunity to compare outcomes in the decentralised programme municipalities versus other, less decentralised, non-programme municipalities. It should be kept in mind that participation in the programme was not randomised. The municipalities decided themselves whether to apply and it was later decided by the government which applicants to accept into the programme.

It is of interest to note that among those accepted were 13 municipalities that declined to participate. ${ }^{11}$ According to our informal conversations with government officials, there seems to be two major reasons behind the choice to withdraw. ${ }^{12}$ Firstly, the full details of the programme were not finalised during the period when applications were due. In particular, it was disclosed only later that participation in the programme would involve no financial transfers from the government to the municipalities. Secondly, some municipalities were of the opinion that they could achieve their objectives regarding labour market policy without taking part in the programme.

\subsection{Diverging objectives?}

In this section we examine the objectives, and potential divergence of objectives, of the government (the principal) and the ESCs (the agents). Government objectives can be found in official policy documents, while information about

\footnotetext{
${ }^{10}$ This assumption is based on discussions with government officials and on articles in various local newspapers.

${ }^{11}$ The withdrawals were Arvika, Kalix, Karlskoga, Lysekil, Mariestad, Ronneby, Skara, Surahammar, Trollhättan, Töreboda, Uddevalla, Vänersborg and Örnsköldsvik.

${ }^{12}$ Information supplied March 16, 1999, by Runar Eriksson, Ministry of Labour, who was in charge of the government's negotiations with the municipalities, and confirmed June 28, 2000, by Håkan Hellstrand, the Swedish Association of Local Authorities, who was a member of a reference group for the pilot programme.
} 
the objectives of the ESC members is not as readily available. ${ }^{13}$ However, a questionnaire was distributed to members in 1999, the results of which are reported in Lundin (1999).

\subsubsection{Government objectives at the national level}

According to various policy documents the purpose of the ESCs is to design labour market policies with due consideration to local conditions and needs. The activities of the ESCs should also take into account national objectives. It is, for example, stated that it is important that the committees look for solutions outside the borders of the municipality. ${ }^{14}$

Since the ESCs are part of the National Labour Market Administration the rules that concern the public authority overall also apply to the committees. ${ }^{15}$ Accordingly, the ESCs should do the following:

- match jobseekers with vacancies

- counteract lock-in effects and inflationary bottlenecks

- increase flexibility on the labour market

- adapt labour market programmes to the individual and strengthen his or her chances of getting a job. However, the activities should not distort competition or cause displacement effects

- protect weak groups on the labour market, especially older people and the occupationally handicapped

There are also quantitative goals for labour market policy, defined on a year-by-year basis, which indirectly affect the ESCs. ${ }^{16}$

\footnotetext{
${ }^{13}$ It should be noted that the document beslutsordning, discussed in the beginning of Section 3, does not specify any objectives regarding the ESCs, only assignments of tasks. Thus there seems to be no need to, or possibility of, considering the regional level when examining the divergence of objectives.

${ }^{14}$ See Government Regulation (1988:1139) and Government Bill (1995/96:222).

${ }^{15}$ Government bill (1998/1999:1), Government Regulation (1988:1139) and Government Regulation (1987:405). For a summary of the rules that concern Swedish labour market policy, see Bergeskog (1999).

${ }^{16}$ For example, according to the "efficiency goals" for 1999 at least 90 percent of the job vacancies should be filled, the number of long-term unemployed should not, on average, exceed 50,000 persons per month and the share in employment within 90 days after vocational labour market training should be, at least, 70 percent.
} 


\subsubsection{Committee members' objectives at the local level}

Table 1 is based on a questionnaire that was distributed to a sample of ESC members in 1999. The table, broken down by affiliation, shows the objectives that the members find relevant for the committees.

The largest group among the respondents, around half, is representatives of the municipalities. ${ }^{17}$ On average, about 80 percent of this group are local politicians and the rest civil servants. It is conceivable that the politicians' responses differ from those of the civil servants, but it was not possible to investigate this issue. One-fifth of the total is made up of members from the County Labour Boards and PES offices, who, as representatives of the central government, should see to it that the national objectives are upheld at the local level.

A majority of the respondents state that reducing unemployment and increasing employment are important objectives. Considering that a fundamental goal of the government is to stimulate employment and counteract unemployment it is, in our view, somewhat peculiar that no more than three-quarters consider these to be objectives of the committees. Furthermore, only around half of the members consider better use of local knowledge about the labour market and counteracting inflationary bottlenecks to be relevant goals. This is surprising, since the raison d' être of the "new" ESCs (with a municipal majority) is the possibility they offer of adapting labour market policy to local conditions.

\footnotetext{
${ }^{17}$ The share of respondents from municipalities (47.4 percent) is lower than the corresponding share in the full sample, since non-respondents were somewhat overrepresented in this group. According to Lundin (1999) municipalities formed the majorities in 56 percent of the committees sampled and were the largest single group in all committees.
} 
Table 1. The objectives of the local employment service committees according to their members, 1999. By affiliation. Percentages.

\begin{tabular}{|c|c|c|c|c|c|c|}
\hline Objective & $\begin{array}{l}\text { County La- } \\
\text { bour Boards }\end{array}$ & $\begin{array}{l}\text { Public Em- } \\
\text { ployment } \\
\text { Service }\end{array}$ & $\begin{array}{l}\text { Muni- } \\
\text { cipality }\end{array}$ & Business & $\begin{array}{l}\text { Trade } \\
\text { unions }\end{array}$ & Total \\
\hline Reducing unemployment & 87 & 82 & 74 & 63 & 81 & 77 \\
\hline Increasing employment & 92 & 77 & 74 & 75 & 74 & 76 \\
\hline $\begin{array}{l}\text { Increasing the number of } \\
\text { persons in ALMPs relative } \\
\text { to the number of persons re- } \\
\text { ceiving social assistance }\end{array}$ & 14 & 35 & 40 & 27 & 33 & 34 \\
\hline $\begin{array}{l}\text { Increasing supply of labour } \\
\text { to municipal projects }\end{array}$ & 4 & 11 & 10 & 10 & 15 & $\overline{10}$ \\
\hline $\begin{array}{l}\text { Increasing or maintaining } \\
\text { population }\end{array}$ & 24 & 38 & 31 & 20 & 28 & 29 \\
\hline $\begin{array}{l}\text { Strengthening the use of lo- } \\
\text { cal knowledge about the la- } \\
\text { bour market }\end{array}$ & 80 & 68 & 55 & 44 & 55 & 57 \\
\hline $\begin{array}{l}\text { Eliminating bottle-neck } \\
\text { problems on the labour } \\
\text { market }\end{array}$ & 77 & 59 & 46 & 39 & 42 & 49 \\
\hline Other & 14 & 5 & 9 & 15 & 8 & 9 \\
\hline No. Obs. & 74 & 78 & 360 & 81 & 166 & 759 \\
\hline
\end{tabular}

Source: Lundin (1999).

Notes: The question was formulated as follows: "What is the purpose of the local employment service committees according to your opinion? (Mark as many alternatives as you wish.)"

The results are based on a cluster sample. 83 out of 283 ESCs were randomly selected and the questionnaire was distributed to all committee members. 977 persons received the questionnaire and the response rate was 78.6 percent. The confidence intervals for the total number of ESC members (the rightmost column) are less than 5 percentage points. Most differences across subgroups are insignificant due to small sample sizes. Statistics Sweden assisted with sampling, the construction of the questionnaire and with data collection.

Increasing the number of persons in ALMPs relative to the number of persons receiving social assistance and increasing or maintaining population are two alternatives that relatively many committee members have indicated, about one-third. There are two arguments as to why this may reflect diverging objectives of the principal and the agents.

Firstly, as mentioned the ESCs should look for solutions outside the borders of the municipality and counteract lock-in effects and inflationary bottlenecks. This means, among other things, that it is essential that jobseekers are not locked-in geographically. From a municipal point of view it may however be 
favourable if the population is stable or increases, since a large part of municipal revenues consists of local income taxes. If the committees act with the purpose of achieving population goals, this may run counter to national objectives, such as reducing unemployment and avoiding bottlenecks through geographical mobility. ${ }^{18}$

Secondly, the national government finances (most of) the labour market policy, while the municipalities finance social assistance. Hence, there are incentives for the municipalities to pass on the costs for social policy to the national level. A possible interpretation of the survey results is that the municipalities actually seek to pass on costs for social policy to the government, which is another indication of potentially diverging objectives. It is however possible that local governments are more attentive to the needs of weak groups on the labour market than are the central actors, due to asymmetric information. If this is the case, efficiency may be enhanced, not impeded, by the municipalities' actions. Another possible interpretation of the results is thus that the members from the municipalities have stressed their traditional responsibility for weak groups, which is a relevant goal.

Regarding the questions that are designed to capture goals that the committees are not supposed to strive for, it is seen that the objective "increasing supply of labour to municipal projects", is indicated by only around 10 per cent of the respondents. Furthermore it can be noted that the responses of PES office members, who are supposed to pay attention to national objectives, do not differ very much from the responses of the members from the municipalities in this category of questions.

To the extent that objectives are diverging, this may also reflect unduly "loose" instructions to and/or monitoring of the committees. According to the survey a vast majority of the committee members are of the opinion that their roles and duties are not clearly defined. Another important finding in this context is that only 20 percent of all ESC members regard the education received for the assignment as sufficient (Lundin, 1999).

It should be kept in mind that expressing views in a survey is one thing, acting according to these views may be quite another. For example, it is con-

\footnotetext{
${ }^{18}$ A specific example that suggests that ESCs may try to achieve population goals comes from a municipality with much out-migration in northern Sweden, where the committee decided to shift financial resources from a mobility grant for the unemployed to local labour market programmes. The County Labour Board later repealed the decision. (Protocols of ESC meetings, dated February 21, 1997, and October 29, 1997, municipality of Arjeplog.)
} 
ceivable that the presence of members from County Labour Boards and PES offices effectively restricts the set of possible actions. Another possibility is that the representatives of PES offices and County Labour Boards collude with the members from the municipalities. Thus more information is needed about actual behaviour in the municipalities before any firmer conclusions can be reached. To this issue we shall return below.

\section{Econometric section}

\subsection{Data and evaluation methodology}

The micro-data on individuals used in this study have been extracted from the events database HÄNDEL, compiled by the National Labour Market Board. The database contains information on all persons registered at the PES offices. Information on project organisers has been collected from the Board's database Atgärdsregistret. (The two databases do not contain information on programmes financed exclusively by the municipalities.) The data source for municipal-specific variables is Statistics Sweden.

We have chosen the first and second half-years of 1996 as our periods of study. It is assumed that the first half-year represents the "before" period and the second half-year the "after" period of decentralisation. The latter does not fully correspond to the official programme period (July 1 - September 30), but has been chosen due to the observed delays in implementation (see Section 3.1).

We do not directly observe what the ESCs do, so we focus on two outcome variables that may be indirectly affected by the activities of the committees: interregional jobsearch and participation in ALMPs organised by the municipality. The first variable is intended to pick up geographical lock-in effects and the second variable captures one important aspect of the extent to which decision-making is decentralised to the municipalities. Both variables are dichotomous, where 1 indicates that the individual searches for a job outside the local labour market and is enrolled in a municipal project, respectively. Otherwise the variables take on the value zero.

An important motivation for the choice of the outcome variables is that the lags are quite short in both cases, which is necessary with our limited period of study. As soon as a person registers with the PES office it is indicated whether job search is limited to the local labour market only. It would not be feasible to 
use data on actual migration in order to capture geographical lock-in, since migration typically occurs only after a long lag. ${ }^{19}$ However, Harkman (1988) claims that there is a strong correlation between the interregional jobsearch status, as coded in HÄNDEL, and subsequent moves.

Regarding the initiation of ALMPs, the decision-lags are generally not very long. For example, results in Ohlsson (1993) suggest that the number of persons in job-creation programmes starts to rise three months after an additional grant has been made to a PES office. The decision-lag concerning the particular operator of a programme, which is the most relevant lag in our context, is probably even shorter.

The outcomes in the programme municipalities will be compared to the outcomes in two groups of non-programme municipalities. The first group, the "programme comparisons", is made up of 25 municipalities with labour market characteristics similar to those of the 25 programme areas. These municipalities have been selected by Statistics Sweden (SCB, 1992) and were also used in Behrenz et al. (1999). ${ }^{20}$ Selection criteria include population, employment, educational variables and industry structure. The second group, the "withdrawals", consists of the 13 municipalities that were accepted into the programme but chose not to participate.

It is argued that the preferences for municipal involvement in labour market policy among withdrawals resemble the preferences of those in the pilot programme. The decision to apply must reasonably reflect such preferences, while the decision to withdraw mainly seems to have been due to other factors; lack of additional funding and perceptions that it was possible to achieve objectives outside the programme were cited as reasons for withdrawal. According to a study by Bell et al. (1995) on the effects of training programmes, individuals accepted into the programme, but withdrawing before the start, were the preferred comparisons for evaluation purposes among a number of "internal" groups considered. ${ }^{21}$ While this result does not necessarily carry over to our case, it is at least suggestive of the potential usefulness of employing additional information about the characteristics of the programme.

\footnotetext{
${ }^{19}$ Another drawback with available migration data is that moves that are not labour market related are included.

${ }^{20}$ The programme comparisons are Mark, Sandviken, Karlskrona, Gävle, Götene, Botkyrka, Laholm, Arvika, Stockholm, Jönköping, Alvesta, Eskilstuna, Härnösand, Växjö, Solna, Haninge, Ystad, Vaxholm, Tibro, Västervik, Hultsfred, Ekerö, Berg, Tranås and Tanum.

${ }^{21}$ The group that most resembles our withdrawals is termed "no-shows" in Bell et al. (1995).
} 
In order to assess the effects of the programme, we start by calculating the well-known double difference, or difference-in-difference, which in our case is given by

(1) $\Delta^{2}=\left[Y_{\text {Programme, 1996:II }}-Y_{\text {Programme, 1996:I }]}\right]$

- [Y Programme comparison, 1996:II - $\left.Y_{\text {Programme comparison, 1996:I }}\right]$,

where $Y$ is the outcome variable, expressed as a regional average, and subindices denote region and time.

The assumption behind this estimator is that, were it not for the programme, outcomes would be similar across "comparable" regions. This means that all shocks, except those induced by the programme, had the same effect on the outcome in both areas.

A problem with the approach in (1) is that it may not provide sufficient controls for changes that have occurred in $Y$. A recent development in the evaluation literature is to look for additional observations that are assumed to be unaffected by the programme, but are similar to the programme observations. (See Hamermesh, 1999, for a discussion and references to applications.) In our study, it seems natural to include the withdrawals as an extra comparison region, for reasons discussed above. Thus we will also calculate the triple difference:

(2) $\Delta^{3}=\Delta^{2}-\left\{\left[Y_{\text {Withdrawals, 1996:II }}-Y_{\text {Withdrawals, 1996:I }}\right]\right.$

- [Y $\left.\left.Y_{\text {Withdrawals comparison, 1996:II }}-Y_{\text {Withdrawals comparison, 1996:I }}\right]\right\}$.

Apart from $\Delta^{2}$, this expression includes the withdrawals and their respective comparison group, with similar labour market characteristics (SCB, 1992). ${ }^{22}$ To the extent that the pilot programme does not serve as a binding constraint for municipalities with similar preferences for municipal involvement in labour

${ }^{22}$ The withdrawals comparisons are the following 13 municipalities: Ludvika, Övertorneå, Filipstad, Västervik, Katrineholm, Lidköping, Falköping, Hallstahammar, Tidaholm, Hedemora, Munkedal, Mellerud and Hudiksvall. 
market policy, the estimator in (2) is more likely to capture this property of the programme than is (1).

Regarding the first outcome variable, interregional jobsearch, we will study two groups of individuals: unemployed persons and participants in ALMPs. In HÄNDEL, the unemployed are categorised in various ways. We have chosen persons who are coded as being able to take up employment immediately (category 11). This excludes unemployed persons awaiting, e.g., placements in ALMPs. The chosen category should be the potentially most mobile group in the short run and therefore suitable for studying lock-in effects. As a comparison, participants in ALMPs will be examined. ${ }^{23}$ As an average, around 20 percent are recorded as searching interregionally among the unemployed, while a somewhat lower figure applies for persons in ALMPs.

The second outcome variable, project organiser, is available for only two types of ALMPs: relief work and Objective 3 measures. Nevertheless, these programmes are of particular interest in this study. Relief jobs are often associated with substantial crowding-out effects (see, e.g., Calmfors \& Skedinger, 1995, Dahlberg \& Forslund, 1999, and Skedinger, 1995). If relief workers are close substitutes to the regular workforce in municipal services, there may be incentives for the municipalities to organise relief works. Since the ESCs have been influential regarding Objective 3 measures, this programme is relevant to investigate. During the period of study, about 80 percent of relief workers and 30 percent of Objective 3 participants have participated in projects organised by municipalities. ${ }^{24}$

The data have been divided into two time periods, the first and second half of 1996. Basically the data are two repeated cross-sections of individuals. The observational unit is one spell in the relevant registration category (unemployed or participant in ALMP). This means that one individual may be included more than once in the data, to the extent that the category has changed more than once during the period (e.g., unemployed - ALMP - unemployed). Apparently

\footnotetext{
${ }^{23}$ Due to too few observations in the first half-year of 1996, it was not possible to consider participants in Objective 3 measures.

${ }^{24}$ There are also some programmes where all projects are organised by the municipality, e.g. the Municipal Youth Programme (kommunala ungdomsprogrammet) and Computer Centres (datortek). We have not examined these programmes, due to the analytical disadvantage of having to explain the variation in the total number of participants across municipalities. This factor is held constant when the municipal share in a given ALMP is considered.
} 
miscoded observations, e.g., cases where the registration date is later than the date of deregistration, have been excluded.

The inclusion criteria are the following:

- $\quad$ age 18-64 years

- registration in the category occurred during the relevant half-year

- first-time registration occurred during 1996 (interregional jobsearch only)

The second criterion means, inter alia, that spells continuing into the second period are included in the first half-year only. The third criterion should minimise problems with lags as persons may change jobsearch behaviour over time, without a corresponding change in the coding of interregional search.

We have, as a general rule, classified the data into different regions based on the individual's municipality of residence. This applies to all analyses of interregional jobsearch. When investigating project organisers, a more suitable basis for classification is the municipality of the project organiser. The two variables do not coincide in all cases, due to, e.g., commuting. As this information was available only for Objective 3 programmes, the individual's municipality of residence had to be used for relief works.

Background information about the municipalities is presented in Table 2 below. The data refer to 1995 , i.e., before the pilot programme started. It can be noted that total unemployment (open unemployment plus labour market programmes) is about the same in programme and non-programme areas, around 13 percent. In the former, population has increased by two percent during the period 1991-95, as opposed to stagnation elsewhere. Furthermore, municipal employment accounts for somewhat less of total employment (21 percent) than is the case in the non-programme regions ( 23 percent). The social assistance rate ( 8 percent of the population) is slightly higher in the programme municipalities, but the difference is small. On the whole, there is little evidence to suggest that economic conditions have been worse in the programme areas than elsewhere.

Table 2 also reveals that the indicators take on rather similar values in programme municipalities and programme comparisons. In particular, this is true for change in population. Hence the two regions seem to match quite well as 
far as characteristics are concerned. ${ }^{25}$ However, the withdrawals, as well as the withdrawals comparisons, differ in important respects from the programme municipalities. For example, total unemployment is higher (15 percent) and population has decreased during the period 1991-95. Apparently the economic situation in the withdrawals municipalities has been more problematic than in the programme regions.

Table 2. Pre-programme characteristics of municipalities, 1995. By type of municipality. Means.

\begin{tabular}{|c|c|c|c|c|c|}
\hline \multirow[t]{2}{*}{ Variable } & \multirow{2}{*}{$\begin{array}{c}\text { Pilot } \\
\text { Programme }\end{array}$} & \multicolumn{4}{|c|}{ Non-Programme } \\
\hline & & Total & $\begin{array}{c}\text { Of which } \\
\text { Programme } \\
\text { Comparison }\end{array}$ & $\begin{array}{c}\text { Of which } \\
\text { Withdrawals }\end{array}$ & $\begin{array}{c}\text { Of which } \\
\text { Withdrawals } \\
\text { Comparison }\end{array}$ \\
\hline Population & 48,368 & 29,005 & 66,965 & 29,605 & 22,693 \\
\hline $\begin{array}{l}\text { Population Change } \\
\text { 1991-95, \% }\end{array}$ & 2.2 & 0.3 & 2.0 & -0.2 & -0.9 \\
\hline Unemployment Rate, \% & 7.9 & 7.5 & 7.5 & 8.9 & 8.8 \\
\hline $\begin{array}{l}\text { Labour Market } \\
\text { Programme Rate, \% }\end{array}$ & 4.7 & 5.5 & 4.7 & 6.2 & 6.6 \\
\hline Vacancy Rate, \% & 0.2 & 0.2 & 0.3 & 0.2 & 0.2 \\
\hline $\begin{array}{l}\text { Municipal } \\
\text { Employment, \% }\end{array}$ & 20.6 & 22.5 & 20.2 & 22.4 & 23.7 \\
\hline $\begin{array}{l}\text { Social Assistance Recipi- } \\
\text { ents, \% }\end{array}$ & 7.8 & 7.2 & 7.3 & 7.7 & 7.3 \\
\hline $\begin{array}{l}\text { Socialist Parties' Seats in } \\
\text { Local Council, \% }\end{array}$ & 50.7 & 50.9 & 48.3 & 57.5 & 55.5 \\
\hline No. Obs. & 25 & 263 & 25 & 13 & 13 \\
\hline
\end{tabular}

Note: See text for a list of municipalities included in the programme, withdrawals and comparison groups. Source: Statistics Sweden.

${ }^{25}$ Average population is about one third larger among the comparisons, which is partly explained by the fact that that the largest city in the country, Stockholm, is included in this group. 
In Tables 3 and 4, data on the outcome variables are shown for the two periods that are used in the analysis, i.e., the first and second half-year of 1996. The share of interregional jobsearchers is lower in programme than in nonprogramme areas, but has in both areas increased over time. The extent to which programmes are organised by the municipality differs greatly by programme type. The shares have, however, increased in both types of municipalities (with the exception of relief works in non-programme regions).

Table 3. Registrations as interregional jobsearcher, by type of municipality and period, 1996.

a. Spells of unemployed persons

\begin{tabular}{|l|r|r|r|r|}
\hline \multirow{2}{*}{ Type of municipality } & \multicolumn{2}{|c|}{ I: Jan 1-June 30 } & \multicolumn{2}{c|}{ II: July 1-Dec 31 } \\
\cline { 2 - 5 } & No. Obs. & $\begin{array}{c}\text { Interregional } \\
\text { jobsearchers, } \%\end{array}$ & No. obs. & $\begin{array}{c}\text { Interregional } \\
\text { jobsearchers, \% }\end{array}$ \\
\hline Pilot Programme & 49,714 & 17.61 & 55,872 & 19.09 \\
\hline Non-programme & 307,310 & 20.77 & 338,549 & 21.96 \\
\hline
\end{tabular}

b. Spells of participants in ALMPs

\begin{tabular}{|l|r|r|r|r|}
\hline Type of municipality & \multicolumn{2}{|c|}{ I: Jan 1-June 30 } & \multicolumn{2}{|c|}{ II: July 1-Dec 31 } \\
\cline { 2 - 5 } & No. Obs. & $\begin{array}{c}\text { Interregional } \\
\text { jobseekers, } \%\end{array}$ & No. obs. & $\begin{array}{c}\text { Interregional } \\
\text { jobseekers, \% }\end{array}$ \\
\hline Pilot Programme & 6,919 & 16.79 & 17,304 & 18.04 \\
\hline Non-programme & 42,927 & 20.22 & 99,815 & 21.98 \\
\hline
\end{tabular}


Table 4. Participation in ALMPs organised by the municipality, by type of municipality and period, 1996.

a. Spells of persons in relief works

\begin{tabular}{|l|r|r|r|r|}
\hline \multirow{2}{*}{ Type of municipality } & \multicolumn{2}{|c|}{ I: Jan 1-June 30 } & \multicolumn{2}{c|}{ II: July 1-Dec 31 } \\
\cline { 2 - 5 } & No. obs. & $\begin{array}{l}\text { Organised by the } \\
\text { municipality, } \%\end{array}$ & No. obs. & $\begin{array}{c}\text { Organised by the } \\
\text { municipality, \% }\end{array}$ \\
\hline Pilot Programme & 1,723 & 80.21 & 1,306 & 80.70 \\
\hline Non-programme & 9,881 & 80.20 & 6,718 & 77.82 \\
\hline
\end{tabular}

b. Spells of persons in Objective 3 programmes

\begin{tabular}{|l|r|r|r|r|}
\hline Type of municipality & \multicolumn{2}{|c|}{ I: Jan 1-June 30 } & \multicolumn{2}{|c|}{ II: July 1-Dec 31 } \\
\cline { 2 - 5 } & No. obs. & $\begin{array}{l}\text { Organised by the } \\
\text { municipality, \% }\end{array}$ & No. obs. & $\begin{array}{c}\text { Organised by the } \\
\text { municipality, \% }\end{array}$ \\
\hline Pilot Programme & 477 & 6.50 & 1,953 & 31.80 \\
\hline Non-programme & 6,939 & 24.76 & 15,916 & 29.95 \\
\hline
\end{tabular}

\subsection{The econometric model}

The double and triple differences will be estimated within a regression framework, which allows controlling for differences in various characteristics across regions that may affect outcomes.

(3) $Y_{i, m, t}=a_{0}+X_{i, m, t} a_{1}+Z_{m, t} a_{2}+$

$$
\begin{aligned}
& b_{1} P_{m}+b_{2} P C_{m}+b_{3} W_{m}+b_{4} W_{m}+c 1996: I_{t}+ \\
& d_{1} P_{m} \text { 1996:II }{ }_{t}+d_{2} P_{m} \text { 1996:II } t+ \\
& d_{3} W_{m} \text { 1996:II }{ }_{t}+d_{4} W_{m} \text { 1996:II }{ }_{t}+e_{i, m, t}
\end{aligned}
$$

where subindices denote individual $i$, municipality $m$ and half-year $t . X$ is a vector of person-specific variables and $Z$ is a vector of region-specific variables. The various regions are represented by dummy variables $P$ (programme municipalities), $P C$ (programme comparisons), $W$ (withdrawals) and $W C$ 
(withdrawals comparisons), the reference region being the rest of the country, while the second half-year is captured by the dummy 1996:II.

In this study attention will be focused on the four variables where the region dummies are interacted with the time dummy ( $P$ x 1996:II etc.), since the coefficients may be used for estimation of the "standardised" double and triple differences. Note that

(1') $\Delta^{2^{\prime}}=\mathrm{d}_{1}-\mathrm{d}_{2}$

(2) $\Delta^{3^{\prime}}=\mathrm{d}_{1}-\mathrm{d}_{2}-\left(\mathrm{d}_{3}-\mathrm{d}_{4}\right)$,

which can be compared to the corresponding "raw" double and triple differences in (1) and (2), respectively. Finally, $e$ denotes an error term with the usual properties.

As mentioned earlier, interregional jobsearch and municipal project ownership will be used as dependent variables. It is assumed that interregional jobsearch is determined by the same factors as actual migration, so the standard variables that apply in econometric analyses of regional migration will be used as regressors (see, e.g., Greenwood, 1985, for a survey). This amounts to including the following person-specific variables in $X$ : (i) age, since the payoff to migration should decrease with increasing age; (ii) level of education, which is expected to improve knowledge about job opportunities elsewhere; (iii) foreign citizenship, a control variable which is supposed to pick up informational disadvantages as well as smaller investments in "local networks", hence the expected sign is ambiguous. Regarding the region-wide variables in $Z$, the hypothesis is that labour market conditions, relative to other regions, influence search behaviour. Higher unemployment and a lower vacancy rate will thus encourage out-migration, as assumed in the literature.

Basically the same explanatory variables as above will be used in the regressions with municipal project ownership as the dependent variable. This allows testing the hypothesis of outsider targeting. Outsiders will be defined as persons with primary school education only and/or with non-Swedish citizenship.

\subsection{The econometric results}

The estimation method is binomial logit. In order to check the robustness of the results, we have successively added more controls. In the first set of regressions, only person-specific controls are included, whereas the region-specific 
variables are added in the second set. County dummies, capturing regionspecific fixed effects, are included in the third and final set. The regression tables show the beta parameters, which yield information about the direction of the effects but are not readily interpreted in terms of the marginal impact (see, e.g., Greene, 1993). For some variables, e.g., the interactions that are intended to capture the pilot programme effects, the marginal effects are of particular interest. In those cases the slope coefficients, which indicate the marginal effects of a unit increase in the regressor, will be presented in separate tables or mentioned in the text.

Table 5 shows the estimations for interregional jobsearch. The upper panel presents results for the unemployed and the lower panel displays the regressions for participants in ALMPs. Largely, the regressions perform according to the predictions from migration theory. As age increases, the individual is less inclined to look for jobs outside the local labour market and the negative effect also tends to become larger with age. Higher education is associated with a larger propensity to search interregionally, while non-Swedish citizens are less likely to do so. The latter result particularly applies to citizens from countries outside Western Europe (with the exception of North America). The labour market variables in most cases yield results conforming to expectations. In general, the coefficient is positive for the unemployment variable, i.e., municipal unemployment relative to the country as a whole, while the opposite holds for the relative vacancy rate. However, the vacancy variables come in with an unexpected positive sign in the regressions with county dummies.

The regressions 1.b - 3 in Table 5.b control for type of ALMP. It is seen that persons who are not participating in vocational labour market training (the reference category) are with few exceptions less likely to be registered as interregional jobsearchers. In particular, participants in programmes that are exclusively organised by the municipality, namely the Municipal Youth Programme and Computer Centres tend to search less outside the local labour market. The slope coefficients (not shown) range around -0.05 . Whether the coefficients represent a causal effect of these programmes or is due to selection of individuals with particular characteristics into municipal programmes cannot be inferred from the regressions. 
Table 5. Maximum-likelihood parameter estimates of the binomial logit model, 1996. Dependent variable: Interregional jobsearch.

a. Unemployed persons.

\begin{tabular}{|c|c|c|c|}
\hline Variable & (1.a) & (2) & (3) \\
\hline Age & $\begin{array}{r}-0.0457 \\
(.0018) \\
\end{array}$ & $\begin{array}{r}-0.0441 \\
(.0019) \\
\end{array}$ & $\begin{array}{r}-0.0428 \\
(.0019) \\
\end{array}$ \\
\hline Age Squared x 1,000 & $\begin{array}{l}0.420 \\
(.025)\end{array}$ & $\begin{array}{l}0.394 \\
(.026)\end{array}$ & $\begin{array}{l}0.367 \\
(.026)\end{array}$ \\
\hline $\begin{array}{l}\text { Education: } \\
\qquad \text { High School } \\
\text { University }\end{array}$ & $\begin{array}{l}0.4407 \\
(.0090) \\
1.2820 \\
(.0105)\end{array}$ & $\begin{array}{c}0.4348 \\
(.0092) \\
1.3167 \\
(.0108)\end{array}$ & $\begin{array}{l}0.4136 \\
(.0094) \\
1.3956 \\
(.0110) \\
\end{array}$ \\
\hline Citizenship: & & & \\
\hline Nordic & $\begin{array}{r}-0.1830 \\
(.0220)\end{array}$ & $\begin{array}{r}-0.1689 \\
(.0223)\end{array}$ & $\begin{array}{r}-0.0405 \\
(.0227)\end{array}$ \\
\hline Western Europe & $\begin{array}{r}-0.4611 \\
(.0375)\end{array}$ & $\begin{array}{r}-0.4085 \\
(.0380)\end{array}$ & $\begin{array}{r}-0.2366 \\
(.0385)\end{array}$ \\
\hline Eastern Europe & $\begin{array}{r}-0.5550 \\
(.0276)\end{array}$ & $\begin{array}{r}-0.5566 \\
(.0285)\end{array}$ & $\begin{array}{r}-0.4841 \\
(.0289)\end{array}$ \\
\hline North America & $\begin{array}{r}-0.2730 \\
(.0478)\end{array}$ & $\begin{array}{r}-0.2389 \\
(.0485)\end{array}$ & $\begin{array}{r}-0.1308 \\
(.0494)\end{array}$ \\
\hline South America & $\begin{array}{r}-0.8390 \\
(.0511)\end{array}$ & $\begin{array}{r}-0.7589 \\
(.0514)\end{array}$ & $\begin{array}{r}-0.5755 \\
(.0522)\end{array}$ \\
\hline Asia & $\begin{array}{r}-0.8026 \\
(.0280)\end{array}$ & $\begin{array}{r}-0.7704 \\
(.0284)\end{array}$ & $\begin{array}{r}-0.6269 \\
(.0288)\end{array}$ \\
\hline Africa & $\begin{array}{r}-0.7684 \\
(.0496)\end{array}$ & $\begin{array}{r}-0.7128 \\
(.0506)\end{array}$ & $\begin{array}{r}-0.5205 \\
(.0511)\end{array}$ \\
\hline
\end{tabular}


Table 5.a continued.

\begin{tabular}{|c|c|c|c|}
\hline Variable & (1.a) & (2) & (3) \\
\hline \multicolumn{4}{|l|}{ Type of Municipality: } \\
\hline \multirow[t]{2}{*}{ Pilot Programme $(P)$} & -0.2030 & -0.2500 & -0.1256 \\
\hline & $(.0131)$ & $(.0133)$ & $(.0142)$ \\
\hline \multirow[t]{2}{*}{ Programme Comparison (PC) } & -0.2851 & -0.0930 & 0.0167 \\
\hline & $(.0112)$ & $(.0119)$ & $(.0134)$ \\
\hline \multirow{2}{*}{ Withdrawals (W) } & 0.2870 & 0.2376 & 0.2215 \\
\hline & $(.0201)$ & $(.0204)$ & $(.0210)$ \\
\hline \multirow[t]{2}{*}{ Withdrawals Comparison (WC) } & 0.4665 & 0.3494 & 0.2448 \\
\hline & $(.0221)$ & $(.0223)$ & $(.0229)$ \\
\hline \multirow[t]{2}{*}{ Second Half-year (1996:II) } & 0.1099 & 0.1151 & 0.0916 \\
\hline & $(.0074)$ & $(.0076)$ & $(.0077)$ \\
\hline \multicolumn{4}{|l|}{ Interactions: } \\
\hline \multirow[t]{2}{*}{ P $x$ 1996:II } & 0.0207 & 0.0100 & 0.0253 \\
\hline & $(.0178)$ & $(.0179)$ & $(.0182)$ \\
\hline \multirow[t]{2}{*}{ PC $\times 1996: I I$} & -0.0111 & 0.0301 & -0.0181 \\
\hline & $(.0155)$ & $(.0156)$ & $(.0159)$ \\
\hline \multirow[t]{2}{*}{$W \times 1996: I I$} & -0.0409 & -0.1819 & -0.0303 \\
\hline & $(.0272)$ & $(.0275)$ & $(.0277)$ \\
\hline \multirow[t]{2}{*}{ WC $x$ 1996:II } & -0.0451 & -0.1063 & -0.0191 \\
\hline & $(.0295)$ & $(.0298)$ & $(.0301)$ \\
\hline Municipal Unemployment Rate, & & 0.4045 & 0.3914 \\
\hline Relative to National & & $(.0120)$ & $(.0160)$ \\
\hline Municipal Vacancy Rate, & & -0.2391 & 0.0388 \\
\hline Relative to National & & $(.0051)$ & $(.0054)$ \\
\hline County Dummies & No & No & Yes \\
\hline No. Observations & 751,445 & 726,843 & 726,843 \\
\hline $2 \log L$ & $-745,885$ & $-716,930$ & $-696,411$ \\
\hline
\end{tabular}

Notes: Intercept and county dummies not shown. The reference category for Education is primary school, for Citizenship Swedish and for Type of municipality the rest of the country. Standard errors in parentheses. 
b. Participants in ALMPs.

\begin{tabular}{|c|c|c|c|c|}
\hline Variable & (1.a) & $(1 . b)$ & (2) & (3) \\
\hline Age & $\begin{array}{r}-0.0665 \\
(.0042)\end{array}$ & $\begin{array}{r}-0.0915 \\
(.0050) \\
\end{array}$ & $\begin{array}{r}-0.0911 \\
(.0051) \\
\end{array}$ & $\begin{array}{r}-0.0895 \\
(.0052)\end{array}$ \\
\hline Age Squared $x 1,000$ & $\begin{array}{l}0.702 \\
(.061) \\
\end{array}$ & $\begin{array}{r}1.020 \\
(.069) \\
\end{array}$ & $\begin{array}{l}1.010 \\
(.070) \\
\end{array}$ & $\begin{array}{l}0.987 \\
(.071) \\
\end{array}$ \\
\hline $\begin{array}{l}\text { Education: } \\
\text { High School } \\
\text { University }\end{array}$ & $\begin{array}{r}0.5782 \\
(.0184) \\
1.3114 \\
(.0241) \\
\end{array}$ & $\begin{array}{r}0.5653 \\
(.0185) \\
1.3081 \\
(.0244) \\
\end{array}$ & $\begin{array}{r}0.5600 \\
(.0189) \\
1.3254 \\
(.0249) \\
\end{array}$ & $\begin{array}{r}0.5401 \\
(.0192) \\
1.3985 \\
(.0254) \\
\end{array}$ \\
\hline Citizenship: & & & & \\
\hline Nordic & $\begin{array}{r}-0.2961 \\
(.0507)\end{array}$ & $\begin{array}{r}-0.2929 \\
(.0508)\end{array}$ & $\begin{array}{r}-0.2898 \\
(.0515)\end{array}$ & $\begin{array}{r}-0.2046 \\
(.0524)\end{array}$ \\
\hline Western Europe & $\begin{array}{r}-0.5383 \\
(.0808)\end{array}$ & $\begin{array}{r}-0.5751 \\
(.0809)\end{array}$ & $\begin{array}{r}-0.5438 \\
(.0818)\end{array}$ & $\begin{array}{r}-0.4085 \\
(.0828)\end{array}$ \\
\hline Eastern Europe & $\begin{array}{r}-0.4034 \\
(.0392)\end{array}$ & $\begin{array}{r}-0.4651 \\
(.0397)\end{array}$ & $\begin{array}{r}-0.4719 \\
(.0409)\end{array}$ & $\begin{array}{r}-0.4226 \\
(.0416)\end{array}$ \\
\hline North America & $\begin{array}{r}-0.0656 \\
(.0976)\end{array}$ & $\begin{array}{r}-0.0938 \\
(.0979)\end{array}$ & $\begin{array}{r}-0.0607 \\
(.0989)\end{array}$ & $\begin{array}{r}0.0611 \\
(.1008)\end{array}$ \\
\hline South America & $\begin{array}{r}-0.6226 \\
(.0869)\end{array}$ & $\begin{array}{r}-0.6531 \\
(.0871)\end{array}$ & $\begin{array}{r}-0.6012 \\
(.0882)\end{array}$ & $\begin{array}{r}-0.4760 \\
(.0894)\end{array}$ \\
\hline Asia & $\begin{array}{r}-0.7401 \\
(.0494)\end{array}$ & $\begin{array}{r}-0.7792 \\
(.0495)\end{array}$ & $\begin{array}{r}-0.7581 \\
(.0504)\end{array}$ & $\begin{array}{r}-0.6471 \\
(.0511)\end{array}$ \\
\hline Africa & $\begin{array}{r}-0.6855 \\
(.0935)\end{array}$ & $\begin{array}{r}-0.7319 \\
(.0936) \\
\end{array}$ & $\begin{array}{r}-0.6675 \\
(.0943)\end{array}$ & $\begin{array}{r}-0.4817 \\
(.0953)\end{array}$ \\
\hline Type of ALMP: & & & & \\
\hline Recruitment Subsidy & & $\begin{array}{r}0.1523 \\
(.0301)\end{array}$ & $\begin{array}{r}0.1410 \\
(.0306)\end{array}$ & $\begin{array}{r}0.1946 \\
(.0312)\end{array}$ \\
\hline Start-up Grant & & $\begin{array}{r}-0.2760 \\
(.0368)\end{array}$ & $\begin{array}{r}-0.2634 \\
(.0375)\end{array}$ & $\begin{array}{r}-0.1836 \\
(.0380)\end{array}$ \\
\hline Relief Work & & $\begin{array}{r}-0.0877 \\
(.0433)\end{array}$ & $\begin{array}{r}-0.0953 \\
(.0439)\end{array}$ & $\begin{array}{r}0.0026 \\
(.0447)\end{array}$ \\
\hline Work Experience Scheme & & $\begin{array}{r}-0.0841 \\
(.0220)\end{array}$ & $\begin{array}{r}-0.0897 \\
(.0225)\end{array}$ & $\begin{array}{r}-0.0680 \\
(.0229)\end{array}$ \\
\hline Replacement Scheme & & $\begin{array}{r}-0.4612 \\
(.0331)\end{array}$ & $\begin{array}{r}-0.4856 \\
(.0338)\end{array}$ & $\begin{array}{r}-0.4662 \\
(.0345)\end{array}$ \\
\hline Workplace Introduction & & $\begin{array}{r}-0.0760 \\
(.0216)\end{array}$ & $\begin{array}{r}-0.0746 \\
(.0220)\end{array}$ & $\begin{array}{r}-0.0511 \\
(.0223)\end{array}$ \\
\hline Public Temporary Work & & $\begin{array}{r}0.1982 \\
(.4447)\end{array}$ & $\begin{array}{r}0.2306 \\
(.4495)\end{array}$ & $\begin{array}{r}0.4660 \\
(.4595)\end{array}$ \\
\hline Computer Centre & & $\begin{array}{r}-0.2319 \\
(.0232)\end{array}$ & $\begin{array}{r}-0.2166 \\
(.0237)\end{array}$ & $\begin{array}{r}-0.1191 \\
(.0241)\end{array}$ \\
\hline Municipal Youth Programme & & $\begin{array}{r}-0.3179 \\
(.0256)\end{array}$ & $\begin{array}{r}-0.3302 \\
(.0261)\end{array}$ & $\begin{array}{r}-0.2767 \\
(.0265)\end{array}$ \\
\hline Employability Inst. Programme & & $\begin{array}{r}-0.6221 \\
(.0407)\end{array}$ & $\begin{array}{r}-0.6239 \\
(.0419)\end{array}$ & $\begin{array}{r}-0.5927 \\
(.0424) \\
\end{array}$ \\
\hline
\end{tabular}


Table 5.b continued.

\begin{tabular}{|c|c|c|c|c|}
\hline Variable & (1.a) & $(1 . b)$ & (2) & (3) \\
\hline $\begin{array}{l}\text { Type of Municipality: } \\
\text { Pilot Programme }(P) \\
\text { Programme Comparison }(P C) \\
\text { Withdrawals }(W) \\
\text { Withdrawals Comparison }(W C)\end{array}$ & $\begin{array}{r}-0.1931 \\
(.0355) \\
-0.1120 \\
(.0330) \\
0.2061 \\
(.0513) \\
0.3805 \\
(.0551)\end{array}$ & $\begin{array}{r}-0.1845 \\
(.0356) \\
-0.1121 \\
(.0331) \\
0.2248 \\
(.0515) \\
0.3911 \\
(.0553)\end{array}$ & $\begin{array}{r}-0.2368 \\
(.0359) \\
0.0143 \\
(.0339) \\
0.1754 \\
(.0521) \\
0.2972 \\
(.0557) \\
\end{array}$ & $\begin{array}{r}-0.1180 \\
(.0377) \\
0.0592 \\
(.0362) \\
0.1470 \\
(.0532) \\
0.1684 \\
(.0569)\end{array}$ \\
\hline Second Half-year (1996:II) & $\begin{array}{l}0.0463 \\
(.0168) \\
\end{array}$ & $\begin{array}{l}0.0545 \\
(.0169) \\
\end{array}$ & $\begin{array}{l}0.0363 \\
(.0174) \\
\end{array}$ & $\begin{array}{l}0.0251 \\
(.0176) \\
\end{array}$ \\
\hline $\begin{array}{l}\text { Interactions: } \\
\quad \text { P } x \text { 1996:II } \\
\text { PC } x 1996: I I \\
W \times 1996: I I \\
\text { WC } x 1996: I I\end{array}$ & $\begin{array}{r}-0.0392 \\
(.0418) \\
-0.0722 \\
(.0391) \\
-0.0217 \\
(.0609) \\
0.0416 \\
(.0645)\end{array}$ & $\begin{array}{r}-0.0487 \\
(.0419) \\
-0.0624 \\
(.0392) \\
-0.0298 \\
(.0611) \\
0.0351 \\
(.0647)\end{array}$ & $\begin{array}{r}-0.0346 \\
(.0421) \\
-0.0442 \\
(.0395) \\
-0.1067 \\
(.0616) \\
0.0052 \\
(.0652) \\
\end{array}$ & $\begin{array}{r}-0.0166 \\
(.0428) \\
-0.0798 \\
(.0404) \\
0.0267 \\
(.0621) \\
0.1182 \\
(.0658)\end{array}$ \\
\hline $\begin{array}{c}\text { Municipal Unemployment Rate, } \\
\text { Relative to National }\end{array}$ & & & $\begin{array}{l}0.2904 \\
(.0239) \\
\end{array}$ & $\begin{array}{l}0.4273 \\
(.0324) \\
\end{array}$ \\
\hline $\begin{array}{r}\text { Municipal Vacancy Rate, } \\
\text { Relative to National }\end{array}$ & & & $\begin{array}{r}-0.2068 \\
(.0109) \\
\end{array}$ & $\begin{array}{l}0.0306 \\
(.0115) \\
\end{array}$ \\
\hline County Dummies & $\mathrm{No}$ & $\mathrm{No}$ & $\mathrm{No}$ & Yes \\
\hline No. Observations & 166,965 & 166,965 & 161,102 & 161,102 \\
\hline $2 \log L$ & $-165,749$ & $-165,067$ & $-158,811$ & $-154,329$ \\
\hline
\end{tabular}

Notes: The reference category for Type of programme is Vocational labour market training (AMU). See also notes to Table 5.a.

Before discussing the estimated effects of the pilot programme, we turn to the regressions with municipal project ownership as the dependent variable. The regressions in Table 6 basically repeat the format of the previous table. The top panel refers to relief workers and the bottom one to participants in Objective 3 programmes. 
Table 6. Maximum-likelihood parameter estimates of the binomial logit model, 1996. Dependent variable: Participation in ALMP organised by the municipality.

a. Relief workers.

\begin{tabular}{|c|c|c|c|}
\hline Variable & (1.a) & (2) & (3) \\
\hline Age & $\begin{array}{r}0.0540 \\
(.0129) \\
\end{array}$ & $\begin{array}{r}0.0611 \\
(.0130) \\
\end{array}$ & $\begin{array}{r}0.0574 \\
(.0136) \\
\end{array}$ \\
\hline Age Squared $x$ 1,000 & $\begin{array}{r}-0.780 \\
(.155)\end{array}$ & $\begin{array}{r}-0.860 \\
(.157)\end{array}$ & $\begin{array}{r}-0.830 \\
(.164)\end{array}$ \\
\hline $\begin{array}{l}\text { Education: } \\
\text { High School } \\
\text { University }\end{array}$ & $\begin{array}{r}-0.2955 \\
(.0405) \\
0.2984 \\
(.0707)\end{array}$ & $\begin{array}{r}-0.2535 \\
(.0410) \\
0.3205 \\
(.0714)\end{array}$ & $\begin{array}{r}-0.1803 \\
(.0435) \\
0.3794 \\
(.0744)\end{array}$ \\
\hline Citizenship: & & & \\
\hline Nordic & $\begin{array}{l}0.5216 \\
(.1269)\end{array}$ & $\begin{array}{l}0.6005 \\
(.1284)\end{array}$ & $\begin{array}{l}0.4394 \\
(.1339)\end{array}$ \\
\hline Western Europe & $\begin{array}{l}0.9976 \\
(.2639)\end{array}$ & $\begin{array}{l}0.9504 \\
(.2648)\end{array}$ & $\begin{array}{l}0.8704 \\
(.2720)\end{array}$ \\
\hline Eastern Europe & $\begin{array}{l}0.9308 \\
(.1180)\end{array}$ & $\begin{array}{l}0.8681 \\
(.1138)\end{array}$ & $\begin{array}{l}0.7712 \\
(.1216)\end{array}$ \\
\hline North America & $\begin{array}{l}0.1215 \\
(.1986)\end{array}$ & $\begin{array}{l}0.1078 \\
(.1991)\end{array}$ & $\begin{array}{r}-0.0379 \\
(.2074)\end{array}$ \\
\hline South America & $\begin{array}{l}0.7046 \\
(.2230)\end{array}$ & $\begin{array}{l}0.6443 \\
(.2233)\end{array}$ & $\begin{array}{l}0.3039 \\
(.2318)\end{array}$ \\
\hline Asia & $\begin{array}{l}1.2235 \\
(.1272)\end{array}$ & $\begin{array}{l}1.1769 \\
(.1275)\end{array}$ & $\begin{array}{l}0.9955 \\
(.1305)\end{array}$ \\
\hline Africa & $\begin{array}{l}1.0594 \\
(.1991)\end{array}$ & $\begin{array}{l}1.0342 \\
(.1996)\end{array}$ & $\begin{array}{l}0.7237 \\
(.2048)\end{array}$ \\
\hline Type of Municipality: & & & \\
\hline Pilot Programme (P) & $\begin{array}{l}0.1117 \\
(.0678)\end{array}$ & $\begin{array}{l}0.1900 \\
(.0684)\end{array}$ & $\begin{array}{r}-0.1120 \\
(.0780)\end{array}$ \\
\hline Programme Comparison (PC) & $\begin{array}{l}0.6131 \\
(.0776)\end{array}$ & $\begin{array}{l}0.5384 \\
(.0809)\end{array}$ & $\begin{array}{r}-0.2867 \\
(.0905)\end{array}$ \\
\hline Withdrawals (W) & $\begin{array}{l}0.4006 \\
(.1160)\end{array}$ & $\begin{array}{l}0.5148 \\
(.1170)\end{array}$ & $\begin{array}{l}0.4200 \\
(.1245)\end{array}$ \\
\hline Withdrawals Comparison (WC) & $\begin{array}{l}0.3880 \\
(.1095)\end{array}$ & $\begin{array}{l}0.5196 \\
(.1101)\end{array}$ & $\begin{array}{c}0.1553 \\
(.1189)\end{array}$ \\
\hline Second Half-year (1996:II) & $\begin{array}{r}-0.1306 \\
(.0449)\end{array}$ & $\begin{array}{r}-0.1163 \\
(.0456)\end{array}$ & $\begin{array}{r}-0.1664 \\
(.0480)\end{array}$ \\
\hline
\end{tabular}


Table 6.a continued.

\begin{tabular}{|l|r|r|r|}
\hline Variable & (1.a) & (2) & \multicolumn{1}{|c|}{$(3)$} \\
\hline Interactions: & & & \\
Px 1996:II & 0.1144 & 0.1854 & 0.3068 \\
& $(.1040)$ & $(.1046)$ & $(.1077)$ \\
PC x 1996:II & -0.0215 & -0.0688 & -0.0004 \\
& $(.1131)$ & $(.1137)$ & $(.1216)$ \\
Wx 1996:II & -0.7413 & -0.7993 & -0.5958 \\
& $(.1642)$ & $(.1665)$ & $(.1741)$ \\
WC x 1996:II & 0.3020 & 0.3441 & 0.5046 \\
& $(.1917)$ & $(.1929)$ & $(.1969)$ \\
\hline Municipal Unemployment Rate, & & -0.7331 & 0.0635 \\
Relative to National & & $(.0612)$ & $(.0888)$ \\
\hline Municipal Vacancy Rate, & & 0.0292 & -0.3296 \\
Relative to National & & $(.0296)$ & $(.0332)$ \\
\hline County Dummies & No & No & Yes \\
\hline No. Observations & 19,628 & 19,386 & 19,386 \\
\hline 2 Log L & $-19,244$ & $-18,889$ & $-17,292$ \\
\hline
\end{tabular}

Notes: See notes to Table 5.a. 
b. Participants in Objective 3 programmes.

\begin{tabular}{|c|c|c|c|c|}
\hline Variable & (1.a) & (1.b) & (2) & (3) \\
\hline Age & $\begin{array}{r}-0.0548 \\
(.0102)\end{array}$ & $\begin{array}{l}0.0140 \\
(.0108)\end{array}$ & $\begin{array}{l}0.0064 \\
(.0112)\end{array}$ & $\begin{array}{r}-0.0239 \\
(.0139)\end{array}$ \\
\hline Age Squared $x$ 1,000 & $\begin{array}{l}0.486 \\
(.141)\end{array}$ & $\begin{array}{r}-0.250 \\
(.147) \\
\end{array}$ & $\begin{array}{r}-0.200 \\
(.152) \\
\end{array}$ & $\begin{array}{ll}0.084 \\
(.187) \\
\end{array}$ \\
\hline $\begin{array}{l}\text { Education: } \\
\text { High School } \\
\text { University }\end{array}$ & $\begin{array}{r}-0.0140 \\
(.0373) \\
-0.2234 \\
(.0665) \\
\end{array}$ & $\begin{array}{r}-0.0441 \\
(.0380) \\
-0.2078 \\
(.0676) \\
\end{array}$ & $\begin{array}{r}-0.0651 \\
(.0398) \\
-0.1782 \\
(.0703) \\
\end{array}$ & $\begin{array}{r}-0.2144 \\
(.0504) \\
-0.1669 \\
(.0861) \\
\end{array}$ \\
\hline Citizenship: & & & & \\
\hline Nordic & $\begin{array}{r}-0.2097 \\
(.1234)\end{array}$ & $\begin{array}{r}-0.1786 \\
(.1249)\end{array}$ & $\begin{array}{r}-0.1227 \\
(.1301)\end{array}$ & $\begin{array}{l}0.0794 \\
(.1580)\end{array}$ \\
\hline Western Europe & $\begin{array}{r}-0.8871 \\
(.1886)\end{array}$ & $\begin{array}{r}-0.7792 \\
(.1904)\end{array}$ & $\begin{array}{r}-0.6909 \\
(.1973)\end{array}$ & $\begin{array}{r}-0.5099 \\
(.2483)\end{array}$ \\
\hline Eastern Europe & $\begin{array}{r}-1.0160 \\
(.0853)\end{array}$ & $\begin{array}{r}-0.8751 \\
(.0868)\end{array}$ & $\begin{array}{r}-0.8422 \\
(.0895)\end{array}$ & $\begin{array}{r}-0.3611 \\
(.1152)\end{array}$ \\
\hline North America & $\begin{aligned} &- 1.1927 \\
&(.2668)\end{aligned}$ & $\begin{array}{r}-1.1412 \\
(.2690)\end{array}$ & $\begin{array}{r}-1.1939 \\
(.2897)\end{array}$ & $\begin{array}{r}-0.9135 \\
(.3474)\end{array}$ \\
\hline South America & $\begin{array}{r}-0.8240 \\
(.1905)\end{array}$ & $\begin{array}{r}-0.7463 \\
(.1928)\end{array}$ & $\begin{array}{r}-0.7304 \\
(.1959)\end{array}$ & $\begin{array}{r}-0.7568 \\
(.2184)\end{array}$ \\
\hline Asia & $\begin{aligned} &- 1.0035 \\
&(.0993)\end{aligned}$ & $\begin{array}{r}-0.8475 \\
(.1004)\end{array}$ & $\begin{array}{r}-0.7990 \\
(.1026)\end{array}$ & $\begin{array}{r}-0.7430 \\
(.1210)\end{array}$ \\
\hline Africa & $\begin{array}{r}-1.3416 \\
(.1909) \\
\end{array}$ & $\begin{array}{r}-1.1949 \\
(.1914) \\
\end{array}$ & $\begin{array}{r}-1.0579 \\
(.1991) \\
\end{array}$ & $\begin{array}{r}-1.1761 \\
(.2312) \\
\end{array}$ \\
\hline $\begin{array}{c}\text { Type of Objective } 3 \text { Programme: } \\
\text { Paths to Employment }\end{array}$ & & 0.9274 & 1.1014 & 1.6201 \\
\hline G & & $(.0393)$ & $(.0406)$ & $(.0554)$ \\
\hline Start-up & & $\begin{array}{r}-0.1544 \\
(.0875\end{array}$ & $\begin{array}{r}-0.3974 \\
(.0919)\end{array}$ & $\begin{array}{r}-0.7275 \\
(.1037)\end{array}$ \\
\hline Advisory Service & & $\begin{array}{l}0.3910 \\
(.0566)\end{array}$ & $\begin{array}{l}0.2345 \\
(.0581)\end{array}$ & $\begin{array}{r}-0.3096 \\
(.0703)\end{array}$ \\
\hline Type of Municipality: & & & & \\
\hline Pilot Programme $(P)$ & $\begin{aligned} &- 1.6281 \\
&(.1887)\end{aligned}$ & $\begin{array}{r}-1.7211 \\
(.1892)\end{array}$ & $\begin{array}{r}-1.6028 \\
(.1929)\end{array}$ & $\begin{array}{r}-0.7482 \\
(.2794)\end{array}$ \\
\hline Programme Comparison (PC) & $\begin{array}{l}0.5021 \\
(.0859)\end{array}$ & $\begin{array}{l}0.6354 \\
(.0878)\end{array}$ & $\begin{array}{l}0.4102 \\
(.0914)\end{array}$ & $\begin{array}{l}0.5743 \\
(.1379)\end{array}$ \\
\hline Withdrawals $(W)$ & $\begin{array}{l}2.5031 \\
(.2043)\end{array}$ & $\begin{array}{l}2.4224 \\
(.2063)\end{array}$ & $\begin{array}{l}2.4979 \\
.2112)\end{array}$ & $\begin{array}{l}1.6440 \\
(.2768)\end{array}$ \\
\hline Withdrawals Comparison (WC) & $\begin{array}{r}-1.7082 \\
(.2988)\end{array}$ & $\begin{array}{r}-1.5802 \\
(.3004)\end{array}$ & $\begin{array}{r}-1.5441 \\
(.3015)\end{array}$ & $\begin{array}{r}-1.7750 \\
(.3206)\end{array}$ \\
\hline
\end{tabular}


Table 6.b continued.

\begin{tabular}{|l|r|r|r|r|}
\hline Variable & \multicolumn{1}{|c|}{$(1 . a)$} & \multicolumn{1}{c|}{$(1 . b)$} & \multicolumn{1}{c|}{$(2)$} & \multicolumn{1}{c|}{$(3)$} \\
\hline Second Half-year (1996:II) & 0.2093 & 0.2543 & 0.0764 & 0.0546 \\
& $(.0378)$ & $(.0384)$ & $(.0410)$ & $(.0574)$ \\
\hline Interactions: & & & & \\
Px 1996:II & 1.8047 & 1.8635 & 2.1308 & 2.5926 \\
& $(.1960)$ & $(.1966)$ & $(.2001)$ & $(.2877)$ \\
PCx 1996:II & 0.0870 & 0.0367 & 0.2761 & -0.0835 \\
& $(.1007)$ & $(.1026)$ & $(.1067)$ & $(.1489)$ \\
Wx 1996:II & -0.2472 & -0.3343 & -0.1662 & -1.1011 \\
& $(.2225)$ & $(.2248)$ & $(.2300)$ & $(.3020)$ \\
WC x 1996:II & 2.0697 & 2.0280 & 2.0567 & 1.3886 \\
& $(.3133)$ & $(.3148)$ & $(.3167)$ & $(.3401)$ \\
\hline Municipal Unemployment Rate, & & & -1.8911 & -2.6248 \\
Relative to National & & & $(.0749)$ & $(.1118)$ \\
\hline Municipal Vacancy Rate, & & & -0.3830 & -0.4458 \\
Relative to National & & & $(.0324)$ & $(.0396)$ \\
\hline County Dummies & No & No & No & Yes \\
\hline No. Observations & $-27,285$ & 25,285 & 23,408 & 23,408 \\
\hline 2 Log L & $-27,237$ & $-24,605$ & $-15,844$ \\
\hline
\end{tabular}

Notes: The reference category for Type of Objective 3 programme is the Competence Scheme (Kompetensutveckling). See also notes to Table 5.a.

On the whole, the results suggest that the municipalities target the programmes towards outsiders to a larger extent than is the case with other organisers, as predicted earlier. ${ }^{26}$ Persons with the lowest education, i.e., primary school, tend to be overrepresented. Municipal relief work is targeted towards non-Swedish citizens, and the effect is larger for persons from countries outside Western Europe and North America. The opposite result is obtained for Objective 3 programmes, however, where Swedish citizens are more likely than others to be in a municipal project. In order to keep this result in perspective, it should be remembered that Objective 3 programmes as a whole are strongly targeted towards outsiders, as mentioned in Section 3.

What, then, about the estimated effects of the pilot programme? The double $\left(\Delta^{2}\right)$ and triple $\left(\Delta^{3}\right)$ differences are displayed in Tables 7.a and 7.b. The first two columns reproduce the raw differences, and the estimates in the remaining columns correspond to the various specifications used in the regressions. The

\footnotetext{
${ }^{26}$ In principle, participation in relief works and Objective 3 programmes organised by the municipality, as opposed to other organisers, could be driven by self-selection. The concept of targeting applies also in this case, however.
} 
slope coefficients, on which the calculations are based, are shown in the appen$\operatorname{dix}($ Table $A)$.

Table 7. Estimated effects of the pilot programme. Double $\left(\Delta^{2}\right)$ and triple $\left(\Delta^{3}\right)$ differences, with successively more controls.

a. Interregional jobsearch.

\begin{tabular}{|l|c|c|c|c|c|c|c|c|c|c|}
\hline \multirow{2}{*}{ Group } & \multicolumn{2}{|c|}{ Raw } & \multicolumn{2}{c|}{ Model 1.a } & \multicolumn{2}{c|}{ Model 1.b } & \multicolumn{2}{c|}{ Model 2 } & \multicolumn{2}{c|}{ Model 3 } \\
\cline { 2 - 11 } & $\Delta^{2}$ & $\Delta^{3}$ & $\Delta^{2^{\prime}}$ & $\Delta^{3^{\prime}}$ & $\Delta^{2^{\prime}}$ & $\Delta^{3^{\prime}}$ & $\Delta^{2^{\prime}}$ & $\Delta^{3^{\prime}}$ & $\Delta^{2^{\prime}}$ & $\Delta^{3^{\prime}}$ \\
\hline $\begin{array}{l}\text { Unem- } \\
\text { ployed }\end{array}$ & $0.0054^{\dagger}$ & 0.0077 & 0.0048 & 0.0048 & - & - & -0.0036 & 0.0036 & $0.0068^{\ddagger}$ & 0.0079 \\
\hline $\begin{array}{l}\text { Partici- } \\
\text { pants in } \\
\text { ALMPs }\end{array}$ & 0.0093 & $0.0316^{\dagger}$ & 0.0058 & 0.0117 & 0.0025 & 0.0086 & 0.0018 & 0.0129 & 0.0111 & 0.0192 \\
\hline
\end{tabular}

b. Participation in ALMP organised by municipality.

\begin{tabular}{|l|c|c|c|c|c|c|c|c|c|c|}
\hline \multirow{2}{*}{ Group } & \multicolumn{2}{|c|}{ Raw } & \multicolumn{2}{c|}{ Model 1.a } & \multicolumn{2}{c|}{ Model 1.b } & \multicolumn{2}{c|}{ Model 2 } & \multicolumn{2}{c|}{ Model 3 } \\
\cline { 2 - 10 } & $\Delta^{2}$ & $\Delta^{3}$ & $\Delta^{2^{\prime}}$ & $\Delta^{3^{\prime}}$ & $\Delta^{2^{\prime}}$ & $\Delta^{3^{\prime}}$ & $\Delta^{2^{\prime}}$ & $\Delta^{3^{\prime}}$ & $\Delta^{2^{\prime}}$ & $\Delta^{3^{\prime}}$ \\
\hline $\begin{array}{l}\text { Relief Workers } \\
\begin{array}{l}\text { Objectivive 3 } 3 \\
\text { Programmes }\end{array}\end{array}$ & 0.0269 & $0.1450^{\ddagger}$ & 0.0188 & $0.0980^{\ddagger}$ & - & - & $0.0356^{\dagger}$ & $0.1228^{\ddagger}$ & $0.0425^{\ddagger}$ & $0.1255^{\ddagger}$ \\
\hline
\end{tabular}

Notes: The estimates in Models 1-3 are based on the corresponding columns in Tables 5, 6 and $A$. The significance indicators are based on standard errors for the beta parameters, which may not necessarily be equal to the standard errors for the slope coefficients. $\dagger=$ significance at 10 per cent level. $\ddagger=$ significance at 5 per cent level.

According to Table 7.a there is no evidence of geographical lock-in effects of the pilot programme. On the contrary, the estimates are positive in general, although small and in most cases insignificant. Thus the hypothesis that the propensity to register as an interregional jobsearcher in the programme region decreased during the programme period is rejected. The estimated effects range from zero to one percentage point's increase for the unemployed and from zero to three percentage points' increase for the participants in ALMPs. The results do not differ much across differencing methods or across regression specifications.

Table 7.b summarises the results for municipal programme participation. The hypothesis that local initiatives, in the form of municipalities organising ALMPs, increased in the programme regions receives strong support. The estimated effects are larger for Objective 3 programmes than for relief works (1957 and $2-15$ percentage points, respectively). The triple differences tend to be 
larger than double differences, which suggests that the pilot programme may actually have served as a binding constraint on behaviour. Furthermore, the triple differences are more stable than the double differences across model specifications. A possible interpretation of this result is that the former estimator is better at capturing shocks to the outcome variable.

Do the estimations represent true effects of the programme? It is important to note that the unbiasedness of the estimators hinges on the assumption of exogeneity. Furthermore, the econometric specification in (3) may be too restrictive. These issues are discussed below.

\section{(i) Exogeneity of programme participation}

As mentioned, the data are not experimental in the strict sense. Although the municipalities were not randomly assigned to the programme, it is not unreasonable to assume that being in the programme is exogeneous to the individuals who make decisions about interregional jobsearch classification (i.e., the jobless and PES office workers) and decide on details regarding local labour market projects (i.e., ESC members and PES office workers). ${ }^{27}$ However, this is a difficult problem and we cannot know with certainty that our results represent the true programme effects.

\section{(ii) Exogeneity of programme timing}

We do not know exactly when the (first part of the) pilot programme started and ended in the municipalities. If the timing of the programme is endogenous, the estimates are biased (Morrison Piehl et al., 1999). However, the municipalities were required by law to implement the programme, so we believe that the possibilities to act strategically regarding its timing were limited.

\section{(iii) Duration of programme}

A short programme duration biases the estimated effects towards zero. The duration of our programme may have been too short for lock-in effects to appear, despite the fact that we have chosen quick indicators. Under the assumption that the jobless do not anticipate changes in municipal labour market policy following decentralisation (see Section 2), interregional jobsearch may well be slower to adapt than the behaviour of local authorities. In principle, extending

\footnotetext{
${ }^{27}$ Thus the evaluation problem seems less severe in our case than in analyses of the effects of, e.g., training programmes, where individuals may self-select into the programme.
} 
the period of analysis could mitigate this problem. Unfortunately, it is not suitable in our case to extend the period to include 1997, when all ESCs had a municipal majority, in order to compare outcomes with the programme regions. The latter continued in the second part of the programme in 1997, so conditions have not remained the same there, which limits the usefulness of this approach.

(iv) Allowing for region and time-specific coefficients of control variables

The specification in (3) imposes the restriction that the coefficients in $X$ and $Z$ are the same across regions and over time. We have relaxed this assumption by introducing additional interactions in the regressions. The conclusions from Table 7 remained unchanged.

\section{(v) Allowing for group-specific programme effects}

It is conceivable that aggregating the data over all age groups has obscured lock-in effects for young people. As a further check on our results, we introduced interactions in the regressions allowing for separate programme effects for persons aged 18-24. No lock-in effects were detected, however.

\section{(vi) Allowing for additional control variables}

In the regressions with municipal organiser of ALMPs as the dependent variable, we have added most of the variables in Table 2, not already included, as extra controls. The programme effects did not change much.

\section{Conclusions}

We have evaluated the effects of a pilot programme, which implied a shift towards more decentralised decision-making in labour market policy. To be specific, the programme involved the introduction of a municipal majority in local employment service committees in parts of the country in 1996.

Results from a questionnaire to committee members suggest a nonnegligible divergence between the objectives of the members and the national objectives for labour market policy, as manifested in official documents. For example, committee members seem to put some emphasis on population goals and getting people off social assistance and into labour market programmes. This could impinge on the fulfilment of national objectives regarding mobility of the unemployed and the efficiency of active measures. 
Our econometric results, based on a large micro-data set, indicate that decentralisation spurred local initiatives in the form of a rise in the share of participants in relief works and Objective 3 programmes with the municipality as organiser. Furthermore, targeting on outsiders is, to some extent, more common in municipal projects than in others. We have considered only two types of active measures and the generality of this result as far as other programmes are concerned remains to be investigated. As regards potential consequences of diverging objectives, we have not detected any geographical lock-in effects (although this finding may be due to too brief a programme period). The above findings turned out to be robust to numerous checks.

As far as we know, this is the first econometric study dealing with the issues considered here. It goes without saying that more research on the effects of decentralisation of labour market policy is needed in order to assess the generality of our results. 


\section{References}

Aghion, P \& J Tirole (1997), "Formal and Real Authority in Organizations", Journal of Political Economy, 105, 1-29.

Ams (1996), Ma 3-programmet. The National Labour Market Board, Solna.

Behrenz, L, L Delander, H Niklasson \& E Nyberg (1999), "Utvärdering av Lokal samverkan mot arbetslöshet", Centrum för arbetsmarknadspolitisk forskning, University of Växjö.

Bell, S H, L L Orr, J D Blomquist \& G G Cain (1995), Program Applicants as a Comparison Group in Evaluating Training Programs, W.E. Upjohn Institute for Employment Research, Kalamazoo, Michigan.

Bergeskog, A (1999), ”Arbetsmarknadspolitisk översikt 1999", Stencilserie 1999:7, IFAU, Uppsala.

Calmfors, L (1994), "Active Labour Market Policy and Unemployment: a Framework for the Analysis of Crucial Design Features", OECD Economic Studies, 22, 7-47.

Calmfors, L \& H Lang (1995), "Macroeconomic Effects of Active Labour Market Programmes in a Union Wage-setting Model", Economic Journal, 105, 601-619.

Calmfors, L \& P Skedinger (1995), "Does Active Labour-market Policy Increase Employment? Theoretical Considerations and Some Empirical Evidence from Sweden", Oxford Review of Economic Policy, 11, 91-109.

Dahlberg, M \& A Forslund (1999), "Direct Displacement Effects of Labour Market Programmes: the Case of Sweden", Working Paper 1999:7, IFAU, Uppsala.

De Groot, H (1988), "Decentralization Decisions in Bureaucracies as a Principal-agent Problem", Journal of Public Economics, 36, 323-337. 
European Commission (1996), Employment in Europe. Directorate-General for Employment, Industrial Relations and Social Affairs. Luxembourg.

Fay, R G (1996), "Enhancing the Effectiveness of Active Labour Market Policies: Evidence from Programme Evaluations in OECD Countries", Labour Market and Social Policy Occasional Papers No. 18. Organisation for Economic Co-operation and Development, Paris.

Greene, W A (1993), Econometric Analysis, Macmillan.

Greenwood, M J (1985), "Human Migration: Theory, Models and Empirical Studies", Journal of Regional Science, 25, 521-544.

Hamermesh, D S (1999), "The Art of Labormetrics", NBER Working Paper 6927, National Bureau of Economic Research, Cambridge, Massachusetts.

Harkman, A (1988), "Arbetsmarknadspolitikens effekter på geografisk rörlighet", Rapport från Utredningsenheten 1988:19, The National Labour Market Board, Solna.

King, D N, \& Y Ma (2000), "Decentralization and Macroeconomic Performance", Applied Economics Letters, 7, 11-14.

Lundin, M (1999), "Arbetsförmedlingsnämnderna - en implementeringsstudie", Stencilserie 1999:6, IFAU, Uppsala.

Morrison Piehl, A S, J Cooper, A A Braga \& M Kennedy (1999), "Testing for Structural Breaks in the Evaluation of Programs", NBER Working Paper No.W7226, National Bureau of Economic Research, Cambridge, Massachusetts.

Niklasson, H \& L Torsmark (1994), Att målstyra arbetsmarknadspolitik, Tema Nord, 1994:573.

Nyberg, S \& P Skedinger (1998), Arbetsförmedlingarna - mål och drivkrafter, Ds 1998:16, Expertgruppen för studier i offentlig ekonomi, Ministry of Finance, Stockholm. 
OECD (1995), Employment Outlook. Organisation for Economic Co-operation and Development, Paris.

Ohlsson, H (1993), "Lags in the Effects of Labour Market Policy - an Empirical Analysis of Job Creation Measures", Applied Economics, 25, 343-348.

SAF (1999), För mycket kommunal arbetsmarknadspolitik, The Swedish Confederation of Employers, Stockholm.

SCB (1992), "Lokala arbetsmarknader och förvärvsregioner", Information om arbetsmarknaden 1991:7, Statistics Sweden, Stockholm.

Skedinger, P (1995), "Employment Policies and Displacement in the Youth Labour Market", Swedish Economic Policy Review, 2, 135-171.

Svenska Kommunförbundet (1999), Kommunerna i arbetsmarknadspolitiken en enkätundersökning, The Swedish Association of Local Authorities, Stockholm.

Tirole, J (1986), "Hierarchies and Bureaucracies: On the Role of Collusion in Organizations", Journal of Law, Economics, and Organization, 2, 181-214. 


\section{Appendix}

Table A. Slope coefficients of interaction variables in Tables 5 and 6.

\begin{tabular}{|c|c|c|c|c|}
\hline Interactions & Model 1.a & Model $1 . b$ & Model 2 & Model 3 \\
\hline $\begin{array}{l}\text { Table 5.a: } \\
\qquad \text { P } \times 1996: I I\end{array}$ & 0.0030 & & 0.0015 & 0.0037 \\
\hline PCx 1996:II & -0.0018 & & 0.0051 & -0.0030 \\
\hline Wx 1996:II & -0.0034 & & -0.0152 & -0.0025 \\
\hline WC $x$ 1996:II & -0.0034 & & -0.0079 & -0.0014 \\
\hline $\begin{array}{l}\text { Table 5.b: } \\
\qquad \text { P } x \text { 1996:II }\end{array}$ & -0.0066 & -0.0082 & -0.0059 & -0.0028 \\
\hline PC $\times 1996: I I$ & -0.0124 & -0.0107 & -0.0077 & -0.0139 \\
\hline Wx 1996:II & -0.0021 & -0.0029 & -0.0106 & 0.0027 \\
\hline WC $x$ 1996:II & 0.0038 & 0.0032 & 0.0005 & 0.0108 \\
\hline $\begin{array}{l}\text { Table 6.a: } \\
\quad \text { Px 1996:II }\end{array}$ & 0.0157 & & 0.0256 & 0.0424 \\
\hline PC $x$ 1996:II & -0.0031 & & -0.0100 & -0.0001 \\
\hline$W x$ 1996:II & -0.0574 & & -0.0623 & -0.0464 \\
\hline WC $x$ 1996:II & 0.0218 & & 0.0250 & 0.0366 \\
\hline $\begin{array}{l}\text { Table 6.b: } \\
\qquad \begin{array}{l}\text { P } 1996: I I\end{array}\end{array}$ & 0.2656 & 0.2743 & 0.3246 & 0.3950 \\
\hline PC $x$ 1996:II & 0.0129 & 0.0054 & 0.0422 & -0.0128 \\
\hline Wx 1996:II & -0.0239 & -0.0323 & -0.0166 & 0.1102 \\
\hline WC $x$ 1996:II & 0.1610 & 0.1578 & 0.1662 & 0.1122 \\
\hline
\end{tabular}

